
これらの理由から，制作そのものではなく，コンテンツ 周辺の事象に既存の分析手法を当てはめるという研究が大 半であった。

\section{3. アメリカの優位}

\section{1 アメリカの研究}

コンテンツの制作手法を学術的に研究した数少ない系譜 として, 第 2 次世界大戦から開始された教育工学 (Educational Technology) の教授設計 (Instructional Design）モデルを応用した軍人訓練や教育用の映画やテレ ビ番組の制作研究があるが, 研究の蓋然性についての批判 が少なくない3).

制作技術に関する研究系譜としては，コンテンツのディ ジタル化，そしてそれに伴うコンテンッ制作のダウンサイ ジング，制作技術の開放をもたらした研究群がある．具体 的には，J.C.R.リックライダー (J.C.R. Licklider (1915年〜 1990年)）が触媒となって, 今日のディジタルコンテンツ制 作の基礎技術の大半の開発を導いた事例である.リックラ イダーが指揮した1960年代の研究開発がパーソナルコンピ ュータやインタネット，コンピュータグラフィックス (Computer Graphics), バーチャルリアリティ (Virtual Reality)を生み出すことになったことはよく知られている4). パーソナルコンピュータがコンテンツ制作の主要手段であ り，から，インタネットがコンテンツの主要な流通手段と なりつつあることからして, リックライダーが指揮した研 究開発は，実はコンテンツ技術の研究でもあった。それも 偶然ではなく，リックライダーはコンピュータを「コミュニ ケーションの道具」5) と考えて抒り，彼の支援を受けて，パ ーソナルコンピュータの概念を作るアラン・ケイ(Alan Kay) は, パーソナルコンピュータを「コミュニケーシションの増幅 器」であるとともに「ファンタジーの増幅器」6) とみなし, パ ーソナルコンピュータの原型であるALTOで子どもたちに表 現活動の実験を行っている.

ケイのビジョンを継承し, マサチューセッッ工科大学 (MIT) のニコラス・ネグロポンテ (Nicholas Negroponte) は 1980年, 論文「日曜画家の復活」7) の中で, コンピュータが表 現活動を支援するものであることを説き，この考えの実践と して，1985年MITメディアラボ8)を設立した.コンテンツ制 作が技術革新の産物である以上，これまで遊離していた芸術 と工学の融合, あるいはエンタテイメントと工学の融合が必 要となるが, MITメデイアラボは，その先鞭をつけた。

\section{2 民間企業研究所}

表現技術やエンタテイメント技術の研究開発は, 最近にな るまで民間企業で行われていた．特にウォルト・ディズニ 一社とルーカス・フィルム社が果たした役割は大きかった。

ウォルト・ディズニー (Walt Disney) は,「映画産業の技 術革新があれば他社に先駆けて取り入れるべきだ」9)とい うのが持論だった。トーキー, カラー, 70ミリフィルム10), 新しい音響システムなど, ディズニーはいち早く試みてい
る。テーマパークのためにオーディオアニマトロクス (Audio-Animatronics) ${ }^{11)}$ 開発し, CAPS (Computer Animation Production System) ${ }^{12)}$ によってどのスタジオ よりも早くCGアニメーションに挑戦している.

テーマパークを開発する会社13) 設立し, ウォルト・デ イズニーは，テーマパークのアトラクション開発に従事す るスタッフを, イメージのエンジニアという意味でイマジ ニア (Imagineer) と命名し, その社名をウォルト・ディズニ ー・イマジニアリング社 (Walt Disney Imagineering) とし た ${ }^{14)}$ 。のちに同社はアラン・ケイを副社長に迎え，1996年 に，デイズニー社はディズニー・フェローズという制度を 作り, ダニー・ヒリス (Danny Hillis)， マーヴィン・ミンス キー (Marvin Minsky), シーモア・パパート (Seymour A. Papert) などの研究者をデイズニー・フェローズ ${ }^{15)}$ に任命し たが，2001年に解散した。フランシス・コッポラ (Francis Coppola) のゾーエトロープ社も研究機能を持っていたが, 会社更生法を申請した後，ルーカス・フィルムのILM (Industrial Light \& Magic) が研究機能を引き継ぐことにな った。ルーカス・フィルムは2005年, サンフランシスコに ディジタル映像制作研究の核都市Letterman Digital Arts Center ${ }^{16)}$ を建設した。アニメーション工房の一つに過ぎな かったディズニー社は世界最大のメディア企業の一つとな り, ILMが世界最大の特撮工房になったのも, 研究開発機 能を有していたからに他ならない.

\section{3 アメリカの大学の研究所}

アメリカには芸術系と工学系が融合した大学の付置研究 所としては以下のようなものがある.

(1) MITメディアラボ

(2) カーネギー・メロン大学エンタテイメント工学セン ター (Entertainment Technology Center) : 芸術学部 とコンピュータ・サイエンス学部が共同で運営

(3) 南カリフォルニア大学エンタテイメント工学センタ - (Entertainment Technology Center) ${ }^{17)}$

(4) 南カリフォルニア大学統合メディア・システムズ・ センター (Integrated Media Systems Center) ${ }^{18)}$

(5) 南カリフォルニア大学ロバート・ゼメキス・ディジ タル芸術センター (Robert Zemeckis Center for Digital Arts)

(6) カリフォルニア大学アーバイン校 (UCI) ゲーム・カ ルチャー\&テクノロジー・ラボ (Game Culture \& Technology Lab）：開設準備中. 2003年夏, グレ イ・デイビス知事が先頭に立って進めてきた州の科 学・技術革新イニシアチブである『Cal- (IT) 2』プロ グラムの一環として, 研究開発施設である本センタ 一の承認を得ている19).

\section{4. わが国の研究の劣勢}

4.1 わが国の研究

アメリカのACM SIGGRAPHのようにCGを中核とした表

(9) 1757 
現者までも含んだディジタルコンテンツ制作に関する学会 がわが国には存在しない。テレビジョン学会（現，映像情 報メデイア学会) (1925年設立), 日本出版学会 (1969年設立) 20)や日本映像学会 (1974年設立) ${ }^{21)}$ がすでにあり，20世紀 後半から表現形式ごとの学会, 例えば日本アニメーション 学会 (1998年設立) ${ }^{22)}$, 日本漫画学会 (2001年設立) ${ }^{23)}$ ，ゲ 一ム学会 (2002年設立) ${ }^{24)}$ ，コンテンツクリエーション・ア ンド・コミュニケーション学会 (2003年設立) ${ }^{25)}$ などが設 立されたが，批評と工学系の研究発表がほとんどである。 2005年，映像情報メディア学会が中心となって，関連学会 のみならず，映画テレビ技術協会と「デジタル・コンテン ツシンポジウム」を開催したことは，わが国の表現技術の 研究開発の歴史において画期的な出来事であった.

わが国で制作システムに関する研究開発として注目され ているものとして，カーネギー・メロン大学に移籍した金 出武雄教授のVirtualized Realityがある. 複数のカメラで 同じ被写体を撮影し，視差を使用してコンピュー夕に3D映 像をとり込むシステムであり，動く被写体を取り込むこと が可能だ。従来の撮影だと，撮影した際のカメラアングル を変えることはできないが，Virtualized Realityのシステ ムでは, コンピュー夕内に撮影した空間がそっくり写し取 られているため，後でカメラアングルを決定したり，映像 の修正加工も可能になる.

金出教授の共同研究者であった池内克史東京大学教授は, 視差を利用して3D映像を取り込む技術を利用し，大仏など の文化財のディジタルコンテンツ研究を行っている，一方， 南カリフォルニア大学のポール・デベヴェック（Paul Debevec) は, Virtualized Realityよりも簡便な写真機を利 用して景観を取り达むImage-based Modeling/Renderingを 開発し，映画『The Matrix: Reloaded』(2003年)などで使わ れている。研究があっても，実際の作品で利用できる環境 がわが国には整っていない。

東京大学大学院新領域創成科学研究科メディア環境学研 究室では, 映像制作の工程管理ソフトゥェア「EizoWorks」 ${ }^{26)}$ を2002年に開発し，これまで勘に頼っていた制作方法を， 明示的な根拠のもとに組み立て, 進渉状況をだれもが把握 できるようにするとともに，制作のノウハウを蓄積できる ようにした。さらに，ディジタル化によって映像制作の中 での重要度が増しているポストプロダクションの工程管理 ソフトウェアV-TOOLsも開発した。このようにソフトウ エアにするということは，制作の暗黙知を顕在化して共有 できるようになるということである。

\section{2 教育研究機関の日米比較}

コンテンツ制作に関する学術研究の実勢を示す定量的な データは存在しないが，わが国のコンテンツ研究体制の相 対的脆弱さは，アメリカとの比較に扔いて間接的には示す ことができる．高等教育機関は人材育成機関であるととも に研究機能を有する主たる機関の一つであるため, 機関数 は研究者数をある程度反映している。
表1は，日米の映像関係の大学数を比較したものである. 研究者育成を主たる目的にしている大学院の博士課程の数 が研究の量的格差を反映している．表2は，北米で映画テレ ビについて教えている大学教官の数である. 大学教官がす べて研究者というわけでなく, アメリカでは特にその傾向 は強いが，大学を本務にしている研究者数を推測すること はできる。しかし日本にはこの種のデータすら存在しない. わが国のデータとしては，2004年に『月刊ニューメディ ア』で連載された「メディアの学校」シリーズに，メディア に関する高等教育の一覧が掲載されており，21世紀になっ

表 1 日米映画·映像教育関連大学比較 (2003年)

\begin{tabular}{|l|l|c|c|}
\hline & & 米 国 & 日 本 \\
\hline \hline \multirow{2}{*}{ 大学(学士) } & 映画/映像/テレビ & 445 & \multirow{2}{*}{27} \\
\cline { 2 - 3 } & アニメーション & 82 & \\
\hline \multirow{2}{*}{ 大学院 (修士) } & 映画/映像/テレビ & 126 & \multirow{2}{*}{1} \\
\cline { 2 - 3 } & アニメーション & 37 & \\
\hline \multirow{2}{*}{ 大学院 (博士) } & 映画/映像/テレビ & 37 & \multirow{2}{*}{1} \\
\cline { 2 - 3 } & アニメーション & 8 & \\
\hline
\end{tabular}

*1 数值は該当する講座を設けている大学等の数を示す.

*2 学士はB.A., 修士はM.A., 博士はPh.D.の数を示す.

出所：日本「1998年度全国マスコミ関係講座一覧」

(総合ジャーナリズム研究165号)

米国「The Complete Guide to American Film Schools and Cinema and Television Courses 1994」

$\lceil$ Animation School Directory 1999 Winter $\rfloor$

表2 北米における映画テレビの高等教育機関

\begin{tabular}{|c|c|c|}
\hline & 1980年 & 1990年 \\
\hline 映像コースをもつ機関数 & & 556 \\
\hline 映画の博士号授与機関 & 16 & 10 \\
\hline 映画の修士号授与機関 & 76 & 38 \\
\hline 映画の学士号授与機関 & 227 & 109 \\
\hline 映画の準学士号授与機関 & & 9 \\
\hline テレビの博士号授与機関 & 12 & 4 \\
\hline テレビの修士号授与機関 & 71 & 24 \\
\hline テレビの学士号授与機関 & 252 & 89 \\
\hline テレビの準学士号授与機関 & & 30 \\
\hline 映画かテレビに関係する博士号授与機関 & & 20 \\
\hline 映画かテレビに関倸する修士号授与機関 & & 83 \\
\hline 映画かテレビに関倸する学士号授与機関 & & 300 \\
\hline 映画かテレビに関係する準学士号授与機関 & & 62 \\
\hline ビデオの博士号授与機関 & & 0 \\
\hline ビデオの修士号授与機関 & & 9 \\
\hline ビデオの学士号授与機関 & & 20 \\
\hline ビデオの準学士号授与機関 & & 3 \\
\hline 教官数 & 3126 & 3910 \\
\hline 常勤教官 & 2034 & \\
\hline 非常勤教官 & 1092 & \\
\hline 学生数 & 44183 & 67131 \\
\hline 映画専攻学生数 & 12516 & 45040 \\
\hline テレビ尃攻学生数 & 23356 & 18884 \\
\hline 関連教科専攻学生数 & 8301 & 3207 \\
\hline
\end{tabular}

出典：American Film Institute. The American Film Institute Guide to College Courses in Film and Television, 7th Edition. New York: Prentice-Hall, 1980. American Film Institute. The American Film Institute Guide to College Courses in Film and Television, 8th Edition. New York: ARCO, 1990. 
て, 急激に映像系の学部学科が増えていることが示されて いるが，アメリカには遠く及ばない. 国際競争力があると 言われているわが国のアニメーションやビデオゲームでは あるが, アニメーション学科は東京工芸大学芸術学部に 2003年4月に設置されたのが，わが国初であり，ゲームに 関しても大阪電気通信大総合情報学部にディジタルゲーム 学科が 2003 年 4 月設置されたのが最初である.もともと, わが国の表現活動は家元制という，全権を与える変わりに， 教育機能を特定の家族に委任してきた文化資源の継承制度 があり, 誰もが学べるように暗黙知を顕在化したりする努 力は希薄だった.

上記の二つの表にはゲームのデータが含まれていない が，南カリフォルニア大学 (USC) では, 美術学部, 映画・ テレビ学部, コンピュータ・サイエンス学部が, ゲームを 学際的な副専攻課程として2004年秋学期に開講した. 大規 模な総合大学としては初めての試みになる。これまで, ゲ ームを教育プログラムとして認定しているのは, シアトル のディジペン・インスティテュート・テクノロジーや，ゲ ームアート/デザインに学位を与えているサンフランシス コのアート・インスティテュート・オブ・カリフォルニア などの, より専門的な学校に限られていた. ニューヨーク 大学 (NYU), ワシントン大学は, ビデオゲームをプログ ラムとして認定しており, マサチューセッツ工科大学 (MIT) では, メディア研究の科目でゲームを学べる. カー ネギー・メロン大学は, エンタテイメントテクノロジーで 修士号がとれる唯一の大学である。

\section{5．各国のコンテンツ制作に関する研究開発へ の支援政策}

5.1 アメリカ

高等教育機関の少なさは，人材の供給面での深刻な問題 を引き起こすだけでなく, 研究の質と量, および研究の蓄 積においても影響がないわけはない.アメリカにおいてコ ンテンツの研究開発が盛んなのには別の理由もある. 宇宙 開発に以前ほどの勢いがなく, 冷戦構造が崩れた今日では, 莫大な費用をかけて研究開発した技術を使用して，試行錯 誤や失敗を許容できる分野はエンタテイメントだけだと言 われているからだ.

\section{2 イギリス}

イギリス政府は「クール・ブリタニア・プロジェクト」で クリエイティブ産業支援を集中的に行っていたが，1999年 12 月ディジタルコンテンツ産業の育英を目指す, 報告書 『UK Digital Content: An Action Plan for Growth』を発表 し，ディジタルコンテンツ産業支援の姿勢を明確にした。

\section{3 フランス}

文化は国家で管理するという施政を貫いてきたフランス は，文化と産業の両面からあらゆる手段を駆使してコンテ ンツ産業を支援している。研究支援はフランス国立視聴覚 研究所 (INA) を中心に行われてきたが, それ以外にも研究
機関が設置されるようになっている.フランス南部アング レーム (Angouleme) 市の, 映像核都市構想ポール・イマ ージュ (Pole Image) では, ディジタル映像研究所 (LIN) が設置されている他, 映像に関する高等教育機関三つ, 高 校が二つあり，国立アニメーション・映像センターの国立 研究所が, アニメーション映画学校 (Ecole des Metiers du Cinema d'Animation d'Angouleme) なども設置している.

\section{4 ドイッ}

ドイツ南西部のバーデン・ヴュルテンベルク州・カール スルーエ市は，1977年に開所したZKM（カールスルーエ芸 術・メディア技術センター) を中核として, メディア芸術 の最先端をめざしている.メディアミュージアム, 現代美 術館, メディアテークとともに, 映像メディア研究所, 音 楽・音響研究所が設置されている.

\section{5 韓 国}

韓国では金大中前大統領は，国家予算の $1 \%$ 文化に支 出することを大統領選挙の公約とし, 当選後公約通り実施 し, 韓国文化コンテンツ振興院を設立し, ソウル・アニメ ーション・センターやソウル・ゲーム総合支援センター, 映画博物館 (済州シンョン), 韓国漫画博物館 (プチョン市) を矢継ぎばやに設立するなど，コンテンツ産業を積極的に 支援している．2002年7月には「オンライン・ディジタル・ コンテンツ産業発展法」を制定し，世界コンテンツ市場を 占有する上位5カ国に食い込むことを目標としている。こ ういった施策が功を奏し, 韓国のポップカルチャーがアジ ア諸国で浸透しつつある.2003年2月「第1次オンライン・ ディジタル・コンテンツ産業発展計画」の案を発表し, そ の中でオンラインディジタルコンテンツに関する研究開発 に関して，以下の三つの具体的施策を打ち出している.

(1) 映像コンテンツ技術開発センターの設立：CG等のデ イジタルコンテンツ関連の核心技術を持つため, 電 子通信研究院 (ETRI) を中心とした「映像コンテンツ 技術開発センター」(仮称)を設立する.

(2) オンライン実感型ゲームエンジン技術・特殊映像合成 技術等の開発：ディジタルコンテンツ制作, 管理, 流 通に必要なオンライン実感型ゲームエンジン技術・特 殊映像合成技術等の開発を集中支援する.

(3)『ディジタル・コンテンツ技術協力フォーラム』の結 成：大学がディジタルコンテンツ基礎技術研究を活 発にするよう, ディジタルコンテンツ関連大学IT研 究センター (ITRC) を増やし，民官共同『ディジタ ル・コンテンツ技術協力フォーラム』を構成し, 沉 国家的レベルの体系的な研究開発と標準化活動を推 進する.

\section{6 台 湾}

台湾は 2002 年 8 月,「ディジタル・コンテンツ産業振興オ

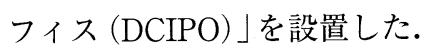

5.7 中 国

中国は, 北京オリンピックや上海万博を目指して, 放送 


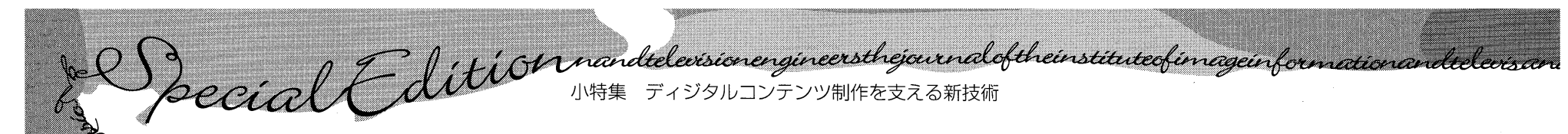

と映画のディジタル化をどこの国よりも早くなしとげよう としている．高度なディジタル技術を駆使したアニメーシ ヨンやゲームの制作技術者を育成するため, 中国・上海の 名門, 上海交通大学が2003年秋から「ディジタルメディア 芸術・技術」を看板に揭げた大学院修士課程を創設する。 従来の教育システムでは, 芸術系と技術系が別々だったが, この課程では海外企業などとも協力し,「芸術とコンピュ 一夕の両方がわかる」専門家を育てる。第 1 期生は $50 \sim 60$ 人 を募集する ${ }^{27)}$.

\section{8 マレーシア}

20世紀末より，マルチメディアスーパーコリドー計画を 実施し, マルチメディア大学を設置して人材育成に努めて いる.

\section{9 シンガポール}

これまで海外に通用するコンテンツを持っていなかった シンガポールは, ディジタルコンテンツ制作のハブを目指 す「メディア21」28) ビジョンを2002年に発表し，「Global Media City」への転換を標榜している. GDPに占めるコン テンツの比率を，1.56\%からここ10年のうちに $3 \%$ にき上 げ，38,000人の雇用を50,000人に引き上げるという目標を 揭げ, 研究施設であるコンテンツ・クリエーション・セン ター (CCC) を設置している.

\subsection{0 日 本}

わが国のコンテンツの共通基盤たるメディア技術の研究 開発は, NHK放送技術研究所とNTTの研究所の, 放送と 通信の二大研究機関に依存してきた. 特にNHK放送技術研 究所は, わが国のみならず世界の放送技術を先導してきた 研究所である. しかし，NHKという組織体の研究所である ため, 大学の付置研究所のような開放性を望むことはでき ないし，放送に限定されている。

このようにみてくると，わが国にはコンテンツ制作に関す る研究機関が皆無であることがわかってくる.こういった 状況について, 国が支援の姿勢をみせつつも, 研究開発機 関が存在しないことについて, 関連業界からも批判の声が 上がっている. 東映の岡田剛社長は次のように述べている.

「映像や音楽などのコンテンツがブロードバンド時代の 有力産業と目されるなか, コンテンツ産業のさまざまな支 援策が検討されている. 関係者から『大規模なス夕ジオ建 設』や『制作費の資金援助』などの政策案を相談されること も多いが，『日本映画をこれからどうしていきたいのか』と いう本質的な視点に欠けている. 今後, 邦画の成長にとっ てカギとなるのはコンピュータグラフィックス技術だ. 制 作費が少ない日本の映画でも米ハリウッドの大作に比する 作品を作ることはできる，だが，民間各社が最先端の技術 と人材を維持していくことは難しい. 邦画の国際競争力を 引き上げるには，民間がCG加工を委託できる世界最先端 の研究機関を設立する策も有効だ.」29)
先に紹介した黒澤明の言葉にあったように, 科学という 認識をもち研究開発を継続して行ってきたアメリカのコン テンツは, どの国のコンテンツ市場に扔いても強い支配力 を持っている，表現の多様性を維持するためにも，制作現 場と連携できる研究開発は不可欠であり, そのための研究 者育成を急がなければならない。

(2005年8月29日受付)

\section{〔文 献〕}

1）黒澤明：“蝦墓の油”, 岩波書店, p.361（1984）

2）エマニュエル・レヴィ：“アカデミー賞全史”，濱口幸一訳，文藝春 秋, p.53 (1992)

3）浜野保樹：“セサミ・ストリートの過誤”, “マルチメデイア・マイン ド”, BNN, pp.257-268.(1993)

4）ハワード・ラインゴールド：“思考のための道具 異端の天才たちは コンピュータに何を求めたか?", 青木真美訳, パーソナルメディア (1987), 浜野保樹：“極端に短いインタネットの歴史”, 晶文社 (1999)

5) J.C.R. Licklider \& R. Taylor: "The Computer as a Communication Device", Science \& Technology (Apr. 1968)

6）浜野保樹監修：“アラン・ケイ”, 鶴岡雄二訳, アスキー, p.133 (1992)

7）ニコラス・P・ネグロポンテ：“日曜画家の復活”，月尾嘉男訳，コン ピュー夕・個人・生活・新情報社会への展望, コンピュータ・エージ 社, pp.59-62 (1980)

8）スチュアート・ブランド：“メディアラボ”，室謙二・麻生九美訳， 福武書店 (1988)

9）グローヴァー，ロン：“ディズニー・タッチ”，仙名紀訳，ダイヤモ ンド社, p.11 (1992)

10)ジョン・テイラー：“ディズニー王国を乗っ取れ”，矢沢聖子訳，文 藝春秋, p.218（1990）

11)フランク・トーマス，オーリー・ジョンストン：“The Illusion of Life 生命を吹き込む魔法”，スタジオジブリ訳，徳間書店，p.532 (2002)

12)ママイケル・アイズナー：“ディズニー・ドリームの発想上”, 布施 由紀子訳, 徳間書店, p.295（2000）

13) The Imagineers. Walt Disney Imagineering: "A Behind the Dream Look at Magic Real", Welcome Enterprises, New York (1996)

14)マーク・エリオット：“闇の王子ディズニー 下”，古賀林幸訳，草 思社, pp.143-144 (1994)

15)“ニューズウイーク日本版”，pp.34-37（1997年8月13日），マイケル . アイズナー：“ディズニー・ドリームの発想 下”，布施由紀子訳， 徳間書店, p.302 (2000)

16) http://www.lucasfilm.com/presidio/

17) http://www.etcenter.org/

18) http://imsc.usc.edu/

19) http://www.hotwired.co.jp/news/news/culture/story/20031117205.html

20) http://www.shuppan.jp/

21) http://www.art.nihon-u.ac.jp/jasias/

22) http://www.zokei.ac.jp/jsas/

23) http://www.kyoto-seika.ac.jp/hyogen/manga-gakkai.html

24) http://www.dmic.org/game/home.shtml

25) http://www.giti.waseda.ac.jp/sccc/

26)浜野保樹：“表現のビジネス”, 東京大学出版会, p.72（2003）

27) http://www.yomiuri.co.jp/net/news/20030822ij81.htm

28) www.mda.gov.sg/MDA/documents/media21.pdf

29）日経新聞，2002年11月4日

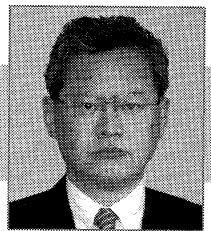

浜野 保樹 国際基督教大学大学院博士後期課 程単位取得退学. 新潟大学教育学部, メデイア教育 開発センターを経て，東京大学大学院新領域創成科 学研究科教授、コンテンツ产業や制作に関する研究 開発に従事. 工学博士. 